\title{
Research on the Development Situation of Industrial Design Industry and Trend Analysis
}

\author{
Tuo Chen \\ Zhijiang college of zhejiang university of technology, Wenzhen 325000, \\ China
}

\begin{abstract}
With the development of economy, human society has entered the Internet era. And people have imposed different requirements on industrial design style. Especially in recent years, industrial design has been developed and become an indispensable part of the modern society. Consequently, the paper studied the development status of industrial design from the international and domestic aspects respectively, and studied the development trend of industrial design.

Keywords:industrial design; development situation; trend
\end{abstract}

\section{Introduction}

In order to satisfy variety requirements of people, various new products have been developed. New products should not only focus on technology, but also have to integrate to modern life concept. Only combining with science and technology, and product design, the product can better promote social development. Therefore, it is necessary to carry out research specific to the development status and trend of industrial design.

\section{Development situation of international industrial design}

International industrial design has been under rapid development since from 1990s. Especially the emergence of new technologies and materials has strengthened product design. To better satisfy the diverse demands of people, 
designers have gradually expanded the design scope and derived a variety of products to make the design more diversified and personalized.

The development speed of international industrial design industry is relatively higher in European and American areas. The development speed of Taiwan, China is also at the international leading position[1]. It has been detected through researches on international industrial design that it shows prominent flexible features and focuses on individualized design. The interactivity of the industrial design of the United States is significant. Product design is no long in simple pattern. According to the investigation of authorities, the ratio between the input and output of industrial design appearance is 1:1500 which indicates that industrial design occupies a very important position.

\section{Development situation of industrial design in China}

China started to develop industrial design at the end of 2001. Manufacturing industry is the first one focusing on industrial design development behavior. In recent years, industrial design has gradually increased attentions on appliance industry, and has launched new products which have greatly satisfied the actual demands of consumers [2]. For further product development, many companies have put great emphasis on hiring qualified industrial designers. In spite of the short-term development of industrial design in China, it has been changed significantly. The specific conditions are as shown in the following table:

Table 1 Development history of industrial design in China

\begin{tabular}{|c|c|}
\hline Time phase & Achievements \\
\hline $\begin{array}{l}15 \text { years } \\
\text { before }\end{array}$ & Over imitation of western design or even indiscriminate imitation \\
\hline $\begin{array}{l}10 \text { years } \\
\text { before }\end{array}$ & New products design is still mainly as imitational design \\
\hline $\begin{array}{l}5 \\
\text { before }\end{array}$ & Independent innovation design has been gradually springing up \\
\hline \multicolumn{2}{|c|}{$\begin{array}{l}\text { It can be seen that as time goes by, industrial design has been gradually } \\
\text { developing. It will gradually become mature. It can be detected from the } \\
\text { researches of domestic industrial design industry that industrial design exists in } \\
\text { China's major cities. Details are shown in Table } 2 \text { below: } \\
\text { Table } 2 \text { Distribution cities and quantity of industrial design companies in China }\end{array}$} \\
\hline City & Qty \\
\hline Guangzhou & $10 \mathrm{co}$ \\
\hline Shenzhen & 8 companies \\
\hline Taiwan & 200 companies \\
\hline Hong Kong & 40 companies \\
\hline Beijing & 15 companies \\
\hline Shanghai & 18 companies \\
\hline
\end{tabular}


Through Table 2 above, it can be seen that among these cities, there are many industrial design companies at Taiwan region. However, it has demonstrated that industrial design has gradually developed and has formed a certain scale.

Since industrial design started rather late in China, it still has certain gap to foreign industrial design (as shown in Table 3 below).

Table 3 Gap between China's and international industrial design

\begin{tabular}{|c|c|c|}
\hline Item & Domestic & International \\
\hline $\begin{array}{l}\text { Enterprise } \\
\text { scale }\end{array}$ & $\begin{array}{l}\text { Number of people: } \\
\text { Less than } 30 \\
\text { Capital: Less than } \\
2.5 \text { million }\end{array}$ & $\begin{array}{l}\text { Number of people: } 50-500 \\
\text { Capital: More than } 5 \text { million }\end{array}$ \\
\hline $\begin{array}{l}\text { Talents } \\
\text { structure }\end{array}$ & $\begin{array}{l}\text { Insufficient } \\
\text { innovative talents }\end{array}$ & Numerous innovative talents \\
\hline Service & Incomplete & $\begin{array}{l}\text { Comprehensive and strong } \\
\text { systematicness }\end{array}$ \\
\hline $\begin{array}{l}\text { Designer } \\
\text { quality }\end{array}$ & Poor & Good \\
\hline Ideology & Conservative & Advanced \\
\hline Design cost & Unreasonable & Reasonable \\
\hline $\begin{array}{l}\text { Product } \\
\text { features }\end{array}$ & Mostly imitated & Comparatively creative \\
\hline
\end{tabular}

It can be detected through Table 3 that there are great gap existing between domestic and international industrial design which will directly affect the development of industrial design in China if the gap cannot be reduced. Specific to this situation, related enterprises of China shall constantly develop themselves combining with their practical situation. They shall keep consistent with the international industry as far as possible thus to enhance the international competitiveness of industrial design of China and promote comprehensive development of the enterprises.

\section{Development trend of industrial design}

In recent years, industrial design has gradually developed. All industries have increased the demands for industrial design. Common industry and design include the follows:

Table 4 Industries imposed stricter demands on industrial design

\begin{tabular}{ll}
\hline Conventional industries & Design industry \\
\hline Household appliance industry & Visual communication design industry \\
Transportation & Design industry \\
Environmental design industry & Public design industry \\
\hline It can be seen from the analysis and studies listed in the above Table 4 that there \\
are many industries requiring stricter demands on industrial design. Thus \\
industrial design has favorable development trend in China[3]. In addition, with
\end{tabular}


the improvement of people's living conditions, people gradually imposed stricter requirements on high quality products. Therefore, we should pay more attention on the development of industrial design in our country.

After China becoming a member of WTO, industry design has been consistently improving in China which has significantly promoted national economic development. In order to promote further development of industrial industry, it is required to forecast the future development trend of the industry thus to promote the economic development of the country and satisfy people's actual demands. Specifically speaking, it is mainly reflected in the following aspects.

Firstly, design capability will be smoothly improved. The position of China in the international society has been consistently improving in recent years, and many international industry design companies have been settled in China. Their settlement has promoted the development of industrial design industry to certain degree. Especially the involvement of foreign enterprise design ideas and thoughts has added power to industrial design industry in our country

Secondly, the product design integration has been continuously enhancing. As being driven by foreign advanced ideas, the Product design ability of industrial design industry will increase obviously. The information integration will increase obviously. Domestic enterprises can design more high quality products to satisfy the actual demands of the public[4].

Thirdly, the communication between enterprises has been increasing. Although certain competitions exist among enterprises under the market economy, they communication and contact will also increase consistently to promote the further development of enterprises.

Fourthly, the talents on innovative design have continuously increased. For industrial design industry, the demands on innovative design and talents will increase with its development. Particularly more talented personnel are required for industrial design in the industries as listed in Table 5. Therefore colleges and universities shall carry out training and education of related personnel thus to continuously promote their professional qualities and satisfy their actual demands. Table 5 Industries on industrial design talents and requirements

\begin{tabular}{ll}
\hline Industry & Requirements \\
\hline Automotive & Proficient in foreign languages and master automotive \\
Industry & technology. \\
Thermal & Understand the development trend of thermal energy and put \\
energy and & forward constructive suggestions combining with current actual \\
power & situation. \\
engineering &
\end{tabular}

Thus it can be seen that industrial design industry requires more talents and stricter requirements. The industrial design can develop healthily only with consistent stricter requirements. Therefore, cultivation intensity on industrial design talent shall be enhanced thus to satisfy the actual demands of each industry. 


\section{Conclusions}

We can see from the above researches that industrial design has become an indispensable part of modern industry. Stricter industrial design requirements have been imposed at home and abroad. It is required to learn their development status and accelerate the development of the enterprise combining with actual conditions thus to promote the development of the industry. The paper analyzed and studied the development status of industrial design industry at home and abroad, and pointed out its development trend with the prospect to provide effective reference for related personnel.

\section{References:}

[1]Tang J J, Liang W Z, Hu S H, et al. Present Situation Analysis and Development Trend Forecast of China's Construction Industry[J]. Applied Mechanics \& Materials, 121-126(21):4053-4058, 2011.

[2]PaoLong Chang, ChinTsai Lin, ChiaHo Chan. A RESEARCH SITUATION AND DEVELOPMENT TREND OF RESEARCH PROJECT ON INDUSTRIAL ENGINEERING DEPARTMENT IN NATIONAL SCIENCE COUNCIL[J]. Journal of the Chinese Institute of Industrial Engineers, 18(2):57-70, 2001.

[3]Weng X, An J, Yang H. The Analysis of the Development Situation and Trend of the City-Oriented Cold Chain Logistics System for Fresh Agricultural Products[J]. Open Journal of Social Sciences, 03(11):70-80, 2015.

[4]Castellano M, Stone J R I, Stringfield S. Earning Industry-Recognized Credentials in High School: Exploring Research and Policy Issues.[J]. Journal of Career \& Technical Education, 21(2):7-34, 2005. 